\title{
Nutritional Analysis of Octopus hubbsorum B (Cephalopoda: Octopodidae) from the Pacific Ocean, Acapulco, Guerrero, México
}

\author{
J. Palacios-Abrantes ${ }^{1^{\star}}$, V. Melo-Ruiz ${ }^{2^{\star}}$, B. Urbano ${ }^{3}$, N. Vargas-Martínez ${ }^{2}$, \\ J. J. Falcón-Gerónimo ${ }^{2}$ and C. Gazga-Urioste ${ }^{2}$ \\ ${ }^{1}$ Bren School of Environmental Science and Management, University of California, Santa Barbara, \\ California, USA. \\ ${ }^{2}$ Departamento de Sistemas Biológicos, Universidad Autónoma Metropolitana, Unidad Xochimilco, \\ Mexico. \\ ${ }^{3}$ Laboratorio de Malacología, Instituto de Ciencias del mar y Limnología, Universidad Nacional \\ Autónoma de México, Mexico.
}

Authors' contributions

This work was carried out in collaboration between all authors. Author JPA designed the study, wrote the protocol, carried out laboratory analysis and wrote the first draft of the manuscript. Authors VMR and BU managed the analyses of the study. Author NVM wrote second draft and carried laboratory analysis. Authors JJFG and CGU managed the laboratory analysis and results of the study. All authors read and approved the final manuscript.

Article Information

DOI: $10.9734 / J A L S I / 2017 / 31031$

Editor(s):

(1) Purnachandra Nagaraju Ganji, Department of Hematology and Medical Oncology, Emory University School of Medicine,

Reviewers:

(1) K. Immaculate Jeya Santa, Suganthi Devadason Marine Research Institute, Tuticorin, Tamil Nadu, India.

(2) Adriana Rodríguez Forero, Universidad Del Magdalena, Colombia. (3) Mohammed Suleiman, Umaru Musa Yar'adua University, Katsina, Nigeria. Complete Peer review History: http://www.sciencedomain.org/review-history/17762

Original Research Article

Received $16^{\text {th }}$ December 2016 Accepted $10^{\text {th }}$ January 2017 Published $8^{\text {th }}$ February 2017

\section{ABSTRACT}

Aim: To establish the micro and macronutrient values of $O$. hubbsorum $\mathrm{B}$ and to evaluate its potential contribution to Mexican diet, since this organism is available all year in the Mexican Pacific Coast.

Study Design: Transversal study.

Place and Duration of Study: Samples of Octopus hubbsorum were bought from fishermen in Acapulco, in the Mexican Pacific Coast during Autumn 2016 
Methodology: Five $O$. hubbsorum were bought from local fishermen during the second week of Novermber, 2016. Moisture content was determined using the direct drying method. Protein content was determined according to the principle of the Kjeldahl method. Lipid content determination was carried out by the semicontinuous solvent extraction method. Determination of raw fiber was performed by an acid- alkaline digestion. Calcium and iron content was determined by atomic absorption spectroscopy, whilst phosphorous content analysis was performed by colorimetry.

Results: High amount of water and protein were found in 0 . hubbsorum B, being $64.15 \%$ and $69.38 \%$, respectively. On the other hand, lipids were low and no fiber was found. Finally, the content of $\mathrm{Ca}, \mathrm{Fe}$ and $\mathrm{P}$ in $\mathrm{mg} / 100 \mathrm{~g}$ was $24.33,1.4$ and 120.67 respectively.

Conclusion: Octopus hubbsorum B is a rather good source of proteins. This could help diminishing proteic-caloric malnutrition of people living in coastal areas. However, octopus should be eaten with other nutritional sources to get a balanced diet.

Keywords: Octopus hubbsorum; nutrition; sea food; Mexican diet.

\section{INTRODUCTION}

Mexico is a country with nutrition-related problems, mainly regarding protein-energy deficit and low consumption of minerals and vitamins. This has contributed to Mexico ranking second on adult obesity within countries of the OECD (30\% of the population) [1]. Most of the times this deficit is supplied with a high intake of carbohydrates, which low quality calories result in malnutrition and other health problems [2]. This also generates difficulties during early growth stages and has an important impact on society $[3,4]$.

Octopus has proved to be a good nutrient source [5]. Mexico, with a coastal line of $11,200 \mathrm{~km}$ [6], has exploited octopus since 1980 [7]. The fishery has had a progressive expansion, becoming the 4th most profitable fishery of the country.

On the Mexican littoral, many cephalopods exist but only few octopods are used for human consumption. According to Mexican authorities, only four species of octopods are fished, although there are 15 of these benthonic zone organisms that can be used for many purposes [8-11]. The main octopus fishery in Mexico belongs to the Caribbean species $O$. maya followed by the Pacific $O$. vulgaris [12]. The richness of the Mexican Pacific octopods is comprised between six and nine species, from which two main species are fished: $O$. bimaculatus and $O$. hubbsorum B [11]. However it is also common to catch O. macropus [13]. O. hubbsorum B represents the main octopus fishery in the Mexican Pacific coast [14], though many times is a subsistence fishery. The fishery is carried out by diving between 0-10 meters deep and specimens are caught manually [13]. The fishing season is from March to October, but this varies locally, presenting the higher fishing activity from April to May [12].
O. hubbsorum B was described first in the southern area of the California Gulf. It is distributed from Los Cabos in Baja California Sur state to Nayarit state [9]. Recently it was reported in Salina Cruz, within the State of Oaxaca [15]. However, there are many reasons to believe that it could also be in Chiapas or further south [16]. It is a semelparous species, with a mean size of 9 $\mathrm{cm}$ of mantle length; its body is rounded with strong arms that can be three to four times larger than the head [9]. Reproductive season varies locally, generally associated to warm waters [16].

Most of the studies are directed to understand the biology and fisheries of these organisms [12, 13]. However, there are not studies focusing on O. hubbsorum B as a protein source and as an alternative for Mexican population diet. Hence, the aim of this study is to establish the micro and macronutrient values of $O$. hubbsorum $\mathrm{B}$ and to evaluate its potential contribution to the Mexican diet.

\section{MATERIALS AND METHODS}

\subsection{Sample Collection}

Five specimens of $O$. hubbsorum B were obtained immediately after capture in November (2016) from local fisherman of Acapulco, Guerrero State, Mexico. The organisms were identified using standard literature [8] and transported by land on ice at $-2^{\circ} \mathrm{C}$ to the bromatology laboratory in the Metropolitan Autonomous University (Xochimilco), Mexico City, where they were kept refrigerated until sample preparation.

\subsection{Sample Preparation}

The eight tentacles of each specimen were sliced from the mantle, cut in squares of approximately 
$4 \mathrm{~cm}$ and mixed (400 g) to perform a proximal analysis for the chemical quantification of their macronutrients and micronutrients.

\subsection{Moisture Content}

Moisture content of the sample was determined using the direct drying method. A homogenized sample $(400 \mathrm{~g})$ was dried in an oven at $60^{\circ} \mathrm{C}$ for $36 \mathrm{~h}$. The sample was grinded in a Willey Mill and then passed through a 60 mesh. The fine powder obtained was used for further analysis [17].

\subsection{Protein Content}

Protein content of the sample was determined according to the principle of the Kjeldahl method [18]. The sample $(1 \mathrm{~g})$ was digested with $15 \mathrm{~mL}$ of concentrated $\mathrm{H}_{2} \mathrm{SO}_{4}$, using an electrically heated aluminum block digester. The resulting digest was diluted and then made alkaline with $50 \mathrm{~mL}$ of $40 \% \mathrm{NaOH}$. This was followed by rapid steam distillation of ammonia from the diluted digest into $25 \mathrm{~mL}$ of $4 \%$ boric acid for manual titration with $0.2 \mathrm{~N} \mathrm{HCl}$. A conversion factor of 6.25 was used to convert the measured nitrogen content to protein content. All samples were analyzed in triplicate and the results are expressed as $\mathrm{g} / 100 \mathrm{~g}$ dry basis of sample $[19,20]$.

\subsection{Lipid Content}

Lipid content determination was carried out by the semicontinuous solvent extraction method as follows: The sample $(10 \mathrm{~g})$ was extracted with $180 \mathrm{~mL}$ of petroleum ether on a Soxhlet apparatus (Sigma-Aldrich, México, México) for $10 \mathrm{~h}$. Petroleum ether was removed by evaporation and the residue of lipid was weighed. All samples were analyzed in triplicate and the results are expressed as $\mathrm{g} / 100 \mathrm{~g}$ dry basis of sample [17].

\subsection{Fiber Content}

Determination of raw fiber in the sample $(10 \mathrm{~g})$ was performed by acid hydrolysis digestion with $\mathrm{H}_{2} \mathrm{SO}_{4} 0.255 \mathrm{~N}$ followed by alkaline hydrolysis digestion with $\mathrm{NaOH} 0.313 \mathrm{~N}$ in a Labconco apparatus (Labconco corporation, Kansas city, Mo. USA). The insoluble residue was collected by filtration, dried and weighed. Sample was analyzed in triplicate and results are expressed as $\mathrm{g} / 100 \mathrm{~g}$ dry basis [17].

\subsection{Mineral Content}

Ash content was determined using a dry ashing method. The sample $(10 \mathrm{~g})$ was incinerated in a cold muffle furnace set at $600^{\circ} \mathrm{C}$ for 8 hours until whitish/greyish ash was obtained. Organic matter was burned off and the remanent inorganic material was cooled and weighed. Ash solution for determination of mineral composition was then prepared by dissolving the resulting ash in $100 \mathrm{~mL}$ of $\mathrm{HCl} 1 \mathrm{~N}$ [21]. $50 \mathrm{~mL}$ were taken for the determination of calcium and iron content by atomic absorption spectroscopy [22]. All samples were analyzed in triplicate. The results are expressed as $\mathrm{mg} / 100 \mathrm{~g}$ of sample for ash content and $\mathrm{mg} / 100 \mathrm{~g}$ of sample for each mineral element. Phosphorus was determined by colorimetry [23].

\subsection{Total Available Carbohydrate Content}

The amount of carbohydrates was determined by difference according to equation 1.

$$
\begin{aligned}
& \text { \%carbohydrate }=100 \%-[(\text { protein } \%)+(\text { lipids \%) } \\
& +(\text { minerals \%)+(fiber \%)] }
\end{aligned}
$$

\section{RESULTS AND DISCUSSION}

\subsection{Moisture Content}

Moisture analysis showed that $O$. hubbsorum B has $64.15 \%$ of water, being $35.85 \%$ dry matter (Table 1). In comparison with other studies performed by Cabello et al.; [5] and Valenzuela et al., [24] on different mollusk species, $O$. hubbsorum B contains less moisture than any mollusk analyzed by these authors whose results showed that $O$. Vulgaris contains $79.65 \%$ of water. This means that the amount of nutrients contained in $O$. hubbsorum B is greater per unit of weight than the one that could be found in other species, which represents an advantage since it would be possible to get higher levels of nutrients with smaller food portions.

\subsection{Protein Content}

Protein content was found to be $69.38 \%$ (Table 1), so O.hubbsorum B may be considered a good source of proteins in comparison with other species such as $O$. vulgaris from the Colombian Pacific or different mollusks studied previously for other authors [5,24]. This suggests, not only the high nutritional value of this species but also, a large difference within octopus species [5]. This has been studied previously, where findings have 
showed that nutritional values from animals tends to change depending on variables such as habitat, season, sex and diet [5,25-27].

In addition to the aforementioned, $O$. hubbsorum $B$ has more protein than beef or chicken [28,29]. Hence, as part of the diet, $O$. hubbsorum B represents a highly nutritious food that could help to decrease the incidence and prevalence of proteic-caloric malnutrition.

\subsection{Lipid Content}

As can be seen in Table 1, lipid content is low $(2.77 \%)$. However, O. hubbsorum $\mathrm{B}$ has twice as much lipids in comparison with data obtained by Cabello et al. [5] for $O$. vulgaris. On the other hand, according to other authors, beef and chicken contain 5 and $7.75 \%$ of lipids respectively. It is important to remember that no food has all the nutrients required for a healthy and balanced diet. Nevertheless, the results obtained demonstrate that $O$. hubbsorum B could be considered as an alternative to provide an adequate and varied diet in order to improve and maintain health.

\subsection{Fiber Content}

According to the analysis performed, O.hubbsorum B has no fiber, so it would be necessary to supply fiber from another source. This is important due to the valuable benefits that this component may provide. In this context, epidemiologic studies suggested that the risk of getting colon cancer diminishes by fiber consumption and so, between 20 and $30 \mathrm{~g}$ per day of fiber are recommended. Besides; some fiber sources absorb bile acids, cholesterol's main metabolite, so fiber consumption may be helpful for diminishing cholesterol blood levels. In addition, other studies showed that fiber consumption may be an effective mean of reducing blood pressure as well as lowering the risks of coronary heart disease [30,31].

\subsection{Mineral Content}

In Table 2, it can be seen that the content of minerals such as iron is lower than the required for humans (6-8 mg/day). However, though iron is an important mineral for human body development and anemia prevention [32], it is not necessary to consume it in large quantities $[33,34]$ because it is highly stored in the human body. Hence, even the iron value reported for 0 . hubbsorum B is low $(1.4 \mathrm{mg} / 100 \mathrm{~g})$, this animal could be a good source for this mineral.

Table 1. Proximal analysis of O.hubbsorum B.

\begin{tabular}{ll}
\hline Nutrient & Content $(\mathbf{g} / \mathbf{1 0 0} \mathbf{g})$ \\
\hline Moisture & 64.15 \\
Dry matter & 35.85 \\
Protein* $^{*}$ & $69.38 \pm 0.97$ \\
Inorganic matter* $^{*}$ & $7.32 \pm 0.68$ \\
Fiber* $^{*}$ & $0 \pm 0.0$ \\
Lipids $^{\text {Soluble carbohydrates }}{ }^{*}$ & $2.77 \pm 0.24$ \\
\hline \multicolumn{2}{c}{${ }^{*}$ Values are mean of triplicate determination } \\
\multicolumn{2}{c}{ expressed on dry basis. } \\
\multicolumn{2}{c}{ Protein $=$ Nitrogen $_{(\text {tot) }} \times 6.25$}
\end{tabular}

Even though the amount of iron found is low, the results showed suitable levels of minerals for humans in comparison with other mollusk groups $[5,24]$.

On the other hand, the amount of calcium in $O$. hubbsorum B is good enough to satisfy human diet requirements $(1.2 \mathrm{mg} / \mathrm{day})$, which is of great importance due to the valuable functions of this mineral, such as its participation as first and second messenger, which is related to many important processes like the regulation of intracellular calcium and the activation of plenty physiologic responses that involve muscular contraction, hormone and neurotransmitters release, glycogen metabolism and cellular differentiation. It also activates different enzymes like proteases and dehydrogenases [35].

Finally, the amount of phosphorus in 0 . hubbsorum B won't be enough to satisfy human requirements (580 mg/day) [36]. However, as mentioned above, there is no food able to provide every nutrient and even less in the appropriate proportions. So, it is necessary to add some other sources to get the phosphorus needed. In this context, Mexican diet includes beans, a high phosphorous food [4] that could aid to overcome the lack of it in $O$. hubbsorum $\mathrm{B}$.

Table 2. Minerals content of O.hubbsorum B.

\begin{tabular}{ll}
\hline Mineral & Content $(\mathbf{m g} / \mathbf{1 0 0} \mathbf{g})$ \\
\hline $\mathrm{Ca}$ & $24.33 \pm 3.06$ \\
$\mathrm{Fe}$ & $1.40 \pm 0.26$ \\
$\mathrm{P}$ & $120.67 \pm 1.15$ \\
\hline
\end{tabular}

\subsection{Total Available Carbohydrate Content}

The total amount of soluble carbohydrates found is $20.53 \mathrm{~g} / 100 \mathrm{~g}$ however, due to the high 
amount of protein found $(69.38 \mathrm{~g} / 100 \mathrm{~g})$; The excess of proteins could be transformed by gluconeogenesis into carbohydrates which will act as a source of energy. So, immediate energy sources like carbohydrates could be obtained through metabolic processes.

\section{CONCLUSION}

Octopus hubbsorum B can be considered a rather good source of proteins. This could be helpful for diminishing proteic-caloric malnutrition of people living in coastal areas. However, despite of its nutritional richness, octopus should be eaten with other nutritional sources to get a balanced diet.

\section{ETHICAL DECLARATION}

The authors have obtained all necessary ethical approval from suitable institutional or state or national or international committee.

\section{COMPETING INTERESTS}

Authors have declared that no competing interests exist.

\section{REFERENCES}

1. OECD. Obesity update. International association for the study of obesity. Organization for Economic Co-operation and Development; 2012.

2. Tilman, D, Clark M. Global diets link environmental sustainability and human health. Nature. 2014;1-15.

Available:http://doi.org/10.1038/nature1395 $\underline{9}$

3. FAO (Food And Agriculture Organization of the United Nations). The State of World Fisheries and Aquaculture. Rome. 2012; 57.

4. Martínez-Jasso I, Villezca P. La alimentación en México: Un estudio a partir de la encuesta nacional de ingresos y gastos de los hogares. Revista de Información y Análisis. 2003;21:26-37. (Spanish).

5. Cabello AM, Lezama RV, Garcia BE, Marcano MC, Figueroa YD, Gonzalez MV. Freshness parameters of mollusks. Rev. Centif. 2004;14:457-466.

6. INEGI (Instituto nacional de Estadística y Geografía). México en cifras; 2008. Available:http://www.inegi.gob.mx/inegi/co ntenidos/espanol/acerca/inegi324.asp?c=3 $\underline{24}$
7. SAGARPA. Anuario estadístico de pesca, secretaría de agricultura, ganadería, desarrollo rural, Pesca y Administración, México; 1993.

8. Roper CL, Sweeney MJ, Nauen CE. Species catalog. Cephalopods of the world. An anottated and ilustrated catalogue of species of interest to fiheries. FAO Fisheries Synopsis. 1984;3.

9. Fisher W, Krupp F, Sommer C, Carpenter KE, Niem VH. Guía FAO para la identificación de especies para los fines de pesca pacifico centro-oriental. Plantas $E$ Invertebrados. Rome. 1995;1.

10. Jereb, Roper CF, editors. Cephalopods of the world. An annotated and illustrated catalogue of species known to date. Chambered nautiluses and sepioids (Nautilidae, Sepiidae, Sepiolidae, Sepiadariidae, Idiosepiidae and Spirulidae). Food and Agriculture Organization of the United Nations (FAO) Rome. Species Catalogue for Fishery Purposes. 2005;4(1).

11. DOF (Diario Oficial de la Federación). 24 de Agosto de. Segunda sección. secretaría de agricultura, ganadería y desarrollo rural, pesca y alimentación. Acuerdo por el cual se da a conocer la actualización de la Carta Nacional de Pesca. 2012;236.

12. Alejo-Plata CR, Gómez-Márquez JL, Ramos S, Herrera-Galindo JE. Reproducción, dieta y pesquería del pulpo Octopus (Octopus) hubssorum (Mollusca: Cephalopoda) en la costa de Oaxaca, México. Rev. Biol. Trop. 2009;57(1-2):6378. (Spanish).

13. Alejo-Plata CR, García-Guillen R, HerreraGalindo J. Paralarvas y juveniles de Octopus bimaculatus (Cephalopoda: Octopodidae) en el Pacífico sur de México. Rev. Mex. Biol. Mar. y Oceano. 2012;27(2):359-365. (Spanish).

14. SAGARPA. Anuario estadístico de pesca, secretaría de agricultura, ganadería, desarrollo rural, pesca y administración. Mexico; 2004.

15. López-Uriarte E, Ríos-Jara E, Pérez-Peña M. Range extension for Octopus hubbsorum $B$ (Mollusca:Octopodidae) in Mexican Pacific. Bulletin of Marine Science. 2005;77(2):177-175.

16. Pliego Cardenáz, R. Biología reproductiva del pulpo Octopus hubbsorum B Berry, 1953 (Cephalopoda: Octopodidea) en la Isla de Espíritu santo, golfo de california, México. centro interdiciplinario de las 
ciencias marinas, Instituto Politécnico Nacional (IPN); 2009.

17. Nielsen SS, editor. Introduction to the chemical analysis of food. Jones and Bartlett Publishers. USA; 1994.

18. Association of Official Analytical Chemists (AOAC). Official Methods of Analysis, $16^{\text {th }}$ ed. AOAC International, Washington, DC; 1995.

19. Osborne, DR. Análisis de nutrientes de los alimentos. Acribia. España; 1985.

20. Pearson D. Técnicas de laboratorio para el análisis de los alimentos. Acribia. España; 1989.

21. Curry ASR, Kontt AR. Analist flame atomic absortion spectomerty. In Analytical Methodos Varian; 1969.

22. Tee ES, Rajam K, Young SI, Khor SC, Zakiya HO. Laboratory procedures in nutrient analysis of foods. In Division of Human Nutrition; Kuala Lumpur: Malasya; 1996.

23. Association of Official Analytical Chemists (AOAC). In official methods of analysis of the association of official analytical chemists; Horwitz, W, Ed.; Arlington; 2002.

24. Valenzuela A, Yanes CG, Golusda C. El ostión del Norte Chileno (Argopecten pupuratus) un alimento de alto valor nutricional. Rev. Chil. Nutri. 2011;38(2) 148-155.66. (Spanish).

25. Larence J, Guillet A. Organic composition of tropical, polar and temperate-water echinoderms. Comp. Biochem. Pysiol. 1982;72B(2):28-287.

26. McClintock J, Pearse J. Biochemical composition of antartic echinoderms. Comp. Btochem. Physiol. 1987; 86B(5):683-687.

27. Kodaira M. Composición química y cambios post- morten en pescado, crustáceos y moluscos. Curso-Taller. Avances en biotecnología de organismos marinos de importancia comercial. Porlamar, del 4 al 15 de marzo. Venezuela; 1991.

28. Carvajal GS. Valor nutricional de la carne de: Res, cerdo y pollo. Corporación Fomento Ganadero, San José, Costa Rica; 2001.

29. Arenas ML, Vidal A, Huerta-Sánchez D, Navas Y, Uzátegui-Bracho S, HuertaLeidenz N. Análisis comparativo proximal de minerales entre carnes de iguana, pollo y res. Arch. Lat. de Nut. 2000;50(4):409415. (Spanish).

30. Roskoski R. Bioquímica. $1^{\text {st }}$ edition. McGrawHill, Mexico; 1997.

31. Vahouny GV, Kritchevsky D, editors. Dietary Fiber: Basic and clinical aspects. Plenum Press, New York, NY. USA; 1986.

32. Beard J. Iron. In Bowman B, Russell R, editors. Present knowledge in nutrition, $9^{\text {th }}$ edition; 2006.

33. Hunt JR, Zito CA. Johnson L. Body iron excretion by healthy men and women. Am J Clin Nutr. 2009;89(6):1792-1798.

34. Ray Yip, editor. Bowman B, Russell R. Conocimientos actuales sobre nutrición. Organización Panamericana de la Salud (OPS). Washington, DC. 2003;340-359.

35. Weaver CM. Calcio. In: Bowman BA, Russel RM, editors. Conocimientos actuales sobre nutrición. Organización Panamericana de la Salud, Washington, DC. EUA; 2003.

36. Anderson JB, Sell ML, Garner SC, Calvo MS. Fósforo. In: Bowman BA, Russel RM, editors. Conocimientos actuales sobre nutrición. Organización Panamericana de la Salud, Washington, DC. EUA; 2003.

(0) 2017 Palacios-Abrantes et al.; This is an Open Access article distributed under the terms of the Creative Commons Attribution License (http://creativecommons.org/licenses/by/4.0), which permits unrestricted use, distribution, and reproduction in any medium, provided the original work is properly cited. http://sciencedomain.org/review-history/17762 